\title{
Öz-Yeterlik İnancı ve Bilgi Profesyonelleri İçin Önemi
}

\author{
Self-Efficacy Belief and Its Importance for Information \\ Professionals
}

S. Serap Kurbanoğlu*

\begin{abstract}
Öz
Öz-yeterlik, kişinin bir işi başarıla yapmak için gerekli becerilere sahip olduğu konusundaki inancıdır. Öz-yeterlik inancı insan davranışlarını etkiler. Insan davranışları, gerçekte doğru olandan çok, insanların neyin doğru olduğu yolundaki inancına dayanır. Öğretme/öğretmen yeterliği ise, öğretmenlerin, öğrencilerin performanslarını ve başarılarını etkileme yeteneklerine olan inançları şeklinde tanımlanır ve öğretmenin etkililiği ile yakından ilişkilidir. Bu makalede, "öz-yeterlik" ve "öğretme/ öğretmen yeterliği” olguları üzerinde durulmakta ve bilgi profesyonelleri için önemi tartışılmaktadır.
\end{abstract}

Anahtar sözcükler: Öz-yeterlik, Öğretme yeterliği, Öğretmen yeterliği, Bilgi profesyonelleri.

\begin{abstract}
Self-efficacy refers to a belief in one's ability to successfully perform a particular behaviour or task. Self-efficacy is a factor which influence human behaviour. People's actions are based more on what they believe than on what is objectively true. Teaching/teacher efficacy, on the other hand, is defined as teachers' belief in their ability to affect student performence and achievement, and has a strong relationship with teaching effectiveness. In this paper, not only "self efficacy" and "teaching efficacy" concepts, but also their importance for information professionals are discussed.
\end{abstract}

Keywords: Self-efficacy, Teaching efficacy, Teacher efficacy, Information professionals.

*Prof. Dr.; Hacettepe Üniversitesi Edebiyat Fakültesi Bilgi ve Belge Yönetimi Bölümü 06532 Beytepe-Ankara (serap@hacettepe.edu.tr). 


\section{Giriş}

Öz-yeterlik, Bandura tarafından geliştirilen ve kişilerin sahip oldukları becerileri etkin şekilde kullanabilmeleri için, önce, ilgili alanda özgüven duymaları gerektiğini savunan sosyal öğrenme kuramının (social learning theory)* anahtar kavramıdır (Pajares, 2002). Bandura tarafından 1977'de ortaya atıdıktan sonra öz-yeterlik alanında sayısız araştırma ve yayın yapıldığı görülmektedir. Eğitim, tıp, psikoloji, işletme, uluslararası ilişkiler gibi çok farklı alanlarda yapılan araştırmalar öz-yeterlik inancının davranışlar açısından belirleyici olduğunu göstermektedir (Bandura, 1986, s. 25). Nitekim, Bandura (1986, s. 15), düşüncelerin davranışları etkilediğini kabul etmeyen bir kuramın karmaşık insan davranışlarını açıklamakta yetersiz kalacağını vurgular.

Öz-yeterlik algısı, kişinin bir işi yapmak için gerekli becerilere sahip olduğu konusundaki inancıdır (Bandura, 1994, s. 71). Bandura'ya göre, başarı için gerekli becerilere sahip olmak yeterli değildir; başarı aynı zamanda bu becerilerin etkin şekilde ve güvenle kullanımını gerektirir (Havard ve Atkinson, t.y.). Gawith (1995), kişinin herhangi bir işi yapabilecek beceriye sahip olmasına rağmen bunu yapabileceği konusunda özgüveni yoksa yapamama olasılığı olduğunu belirtir.

\section{Öz-Yeterlik Neden Önemlidir?}

Öz-yeterlik inancı davranışların ve davranış değişikliklerinin ana belirleyicisi olarak tanımlanmakta, Bandura'nın çalışmaları, kişinin becerileri konusundaki inançlarının sadece davranışlarını değil, motivasyonunu ve başarısını da etkilediğini ortaya koymaktadır (Henson, 2001, s. 3). Pajares (2002), insanların istedikleri sonucu yaratacağına inanmadıkları sürece bir konuda girişimde bulunmalarını veya güçlüklerle karşılaştıkları zaman ısrarcı davranmalarını beklememek gerektiğini belirtir. Araştırmalar, kişilerin kendilerini güvenli ve yeterli hissettikleri işleri yapma, kendilerini yeterli hissetmedikleri işlerden kaçma eğilimi gösterdiklerini; istedikleri sonucu alacaklarına inanmadıkları sürece harekete geçmek konusunda isteksiz davrandıklarını; bir iş yaparken gösterecekleri gayretin düzeyini eylemlerinin tahmini sonucuna göre ayarladıklarını; sonuç olarak, öz-yeterlik inançlarının seçimlerinde etkili olduğunu göstermektedir (Bandura, 1986, s. 129, 393).

\footnotetext{
* Bandura, bu kuramı daha sonra sosyal bilişsel kuram (social cognitive theory) olarak isimlendirmeyi tercih etmiştir.
} 
Pozitif yeterlik inancı taşıyan kişilerin isteyerek eyleme girişmelerinin yanı sıra, güçlükler karşısında daha dayanıklı ve ısrarcı oldukları, daha az stresle daha başarılı sonuçlar elde ettikleri gözlenmiştir. Öz-yeterlik inancı artıkça gösterilen gayret, dayanıklılık ve azim de artmaktadır. Diğer taraftan, öz-yeterlik inancı zayıf olan kişilerin eylemden kaçındıkları, güçlükler karşısında çabuk pes ettikleri ve daha fazla stresle daha düşük performans gösterip daha başarısız oldukları gözlenmiştir (Gordon, Lim, McKinnon ve Nkala, 1998, s. 54; Pajares, 2002).

Öz-yeterlik, özgüvenden farklı olarak belli bir eylemle/alanla ilgilidir. Bir alanda güçlü öz-yeterlik inancı taşıyan kişinin başka bir alanda zayıf öz-yeterlik inancı taşıması olasıdır (Cassidy ve Eachus, 2002). Öz-yeterlik algısı gerçek yeterlik düzeyinden çok, yeterlik düzeyi hakkındaki inançla ilgilidir. Bandura (1995, s. 2), insan davranışlarının gerçekte doğru olandan çok, insanların doğru olduğuna inandığı şeye dayandığı saptamasını yapar. Bu önemli bir ayrımdır, insanlar, genellikle yeterlilik düzeyleri hakkında gerçekte olduğundan düşük veya yüksek olduğu inancına sahiptir. Diğer bir deyişle, insanların kapasitelerini hatalı değerlendirdikleri, azımsadıkları veya abartıkları sık rastlanan bir durumdur. Kapasitelerini olduğundan düşük algılamaları kişilerin sahip oldukları becerileri en iyi şekilde kullanabilmelerini engellerken, kişinin gerçek kapasitesini olduğundan biraz daha yüksek algılaması çoğu durumda performans üzerinde pozitif etkide bulunur (Tschannen-Moran, Woolfolk Hoy ve Hoy, 1998, s. 208).

Sonuç olarak, insan davranışları gerçekte kişilerin neyi başarmaya yetkin olduklarından çok, kapasiteleri/yetkinlikleri konusundaki inançlarına dayanır. Bu durum, insan davranışları ile gerçek kapasitelerinin neden bazen birbirini tutmadığını ve benzer bilgi ve becerilere sahip olmalarına rağmen neden performanslarının farklı düzeylerde olabildiğini açıklamaya yardımcı olur. Bir beceriye sahip olmakla onu farklı durumlarda/koşullarda iyi kullanabilmek arasında fark bulunmaktadır. Bu nedenle, Bandura (1986, s. 391), aynı becerilere sahip kişilerin, hatta aynı kişinin farklı durumlarda farklı düzeylerde (kötü, yeterli, çok iyi) performans sergilediklerini belirtir. Pajares (2002) yetenekli pek çok insanın gerçekte sahip oldukları beceriler konusundaki şüphelerinden dolayı sorun yaşadığını vurgular. Çok sınırlı becerilere sahip olmalarına rağmen yeterlilikleri konusunda güvenli insanlar da vardır. Gerekli bilgi 
ve becerilere sahip olmadan ne kadar kuvvetli olursa olsun yeterlik inancı tek başına kişiyi başarıya götürmez. Öz-yeterlik inancı temelde gerekli bilgi ve becerilerin ne kadar güçlü edinildiğine bağlıdır. Buradan insan davranışlarını etkileyen tek faktörün öz-yeterlik inancı olduğu ve kişinin ilgili alanda güçlü öz-yeterlik inancı olmasının bir işi yapması için yeterli olduğu anlamı çıkartılmamalıdır. İnsan davranışları öz-yeterlik dışında başka faktörlerden de etkilenir. Kişinin kendini bir konuda yeterli hissetmesi o işi yapması için tek başına yeterli değildir, güçlü bir öz-yeterlik inancı tek başına davranışı üretmez. İstemedikleri veya gerekli kaynaklardan yoksun oldukları için veya başka herhangi bir nedenden dolayı, insanlar bazı şeyleri yapmamayı tercih edebilirler (Pajares, 2002).

\section{Öz-Yeterlik İnancını Etkileyen Faktörler}

Öz-yeterlik inancı çeşitli faktörlerin etkisiyle gelişir. Yapılan araştırmalar öz-yeterliği etkileyen en önemli faktörlerden birinin deneyim olduğunu ve pozitif deneyimlerin öz-yeterlik algısının güçlenmesini sağladığını göstermektedir (Bandura, 1986, s. 395; Delcourt ve Kinzie, 1993).

Bandura (1986, s. 399; 1995, s. 3), öz-yeterlik algısını etkileyen faktörleri dört grupta toplamıştır: Kişisel deneyimler, başkalarının deneyimlerinden çıkarılan sonuçlar, sosyal onay, kişinin fizyolojik ve duygusal durumu. Bunlardan en kuvvetlisi kişisel deneyimlerdir. Kişiler çeşitli eylemler gerçekleştirir, bu eylemlerin sonuçlarını değerlendirir, değerlendirme sonuçlarını benzer eylemleri gerçekleştirme kapasiteleri konusunda bir yeterlik inancı geliştirmekte kullanır ve geliştirdikleri inançlara uygun hareket ederler (Bandura, 1986, s. 399; 1995, s. 3; Koul ve Rubba, 1999; Pajares, 2002). Başarılı deneyimler öz-yeterlik inancını artırırken, üst üste yaşanan başarısızlıklar öz-yeterlik inancının düşmesine neden olur. Bandura (1986, s. 389), güçlü öz-yeterlik inancının zamanla, başarılı deneyimler sayesinde geliştiğini, direncinin yüksek olduğunu ve arada sırada yaşanan başarısızlıklardan kolay etkilenmediğini belirtir.

Insanlar, kendi eylemlerinin sonuçlarını değerlendirmenin yanı sıra, başkalarını gözleyerek de, başka bir deyişle, başkalarının deneyimlerinden yola çıkarak da öz-yeterlik inancı geliştirirler. Öz-yeterlik inançlarının oluşturulmasında başkalarının deneyimlerinden edinilen bilgiler kişisel deneyimlerden 
elde edilenler kadar etkili değildir. Özellikle, söz konusu alanda deneyimleri yoksa veya çok sınırlıysa insanlar başkalarının deneyimlerinden daha fazla etkilenirler. Başkalarının deneyimleri, kişi, kendisiyle deneyimlerini gözlediği, başka bir deyişle model aldığı kişi arasında benzerlikler görüyorsa daha etkilidir. Yaş, eğitim düzeyi ve/veya cinsiyet gibi özellikleri kendisine benzeyen modelin başarısı kişide ben de yapabilirim/başarabilirim duygusu yaratırken, başarısızlığı kişinin kendi başarma kapasitesi konusunda şüpheye düşmesine neden olabilmektedir (Bandura, 1986, s. 399; 1995, s. 3; Pajares, 2002).

Kişiler öz-yeterlik inançlarını geliştirirken diğer insanlardan gelen tepkilerden de etkilenirler. Bu daha çok, başkalarının, kişinin belli becerilere sahip olduğu yönünde yaptıkları sözlü değerlendirmeleri içerir. Bir işi yapabilecek kapasitede olduğu konusunda dışardan gelen bir değerlendirmenin öz-yeterlik inancı üzerindeki etkisi çok güçlü olmamakla beraber kişinin işi yapmak/başarmak konusunda göstereceği gayreti olumlu yönde etkilediği bilinmektedir. Diğer taraftan olumsuz değerlendirmelerin öz-yeterlik üzerinde zayıflatıcı rol oynadığı bilinmektedir (Pajares, 2002). Bandura (1986, s. 400), olumsuz değerlendirmelerle kişinin öz-yeterlik inancını zayıflatmanın pozitif yüreklendirmelerle öz-yeterlik algısını güçlendirmekten daha kolay olduğunu belirtir (Bandura, 1986, s. 400; Pajares, 2002).

Fizyolojik ve duygusal durumları da insanların kendi kapasitelerini değerlendirirken kullandıkları verilerdir. Insanlar bir konudaki kapasiteleri hakkındaki yeterlik inançlarını o işi yaparken deneyimledikleri fizyolojik ve duygusal reaksiyonlarla da değerlendirebilmektedir. Herhangi bir eyleme karşı kişinin deneyimlediği heyecan, stres, korku gibi güçlü duygusal reaksiyonlar, sonucun başarılı veya başarısız olacağı konusunda ip uçları sağlar. Pozitif duygular, öz-yeterlik inancını güçlendirirken, negatif duygular öz-yeterlik inancını zayıflatır, daha fazla stres ve heyecan yaratır ki bu da sonuçta performansı olumsuz yönde etkiler (Bandura, 1986, s. 401; 1995, s. 4). Pajares (2002) duygusal reaksiyonların her zaman eldeki işle/gerçekleştirilecek eylemle ilgisi olmadığını vurgular. Örneğin, depresif ruh hali içindeki kişilerin yeterlik inançları eldeki işten bağımsız olarak düşebilmektedir. Dolayısıyla negatif psikolojik etkenleri azaltmak öz-yeterlik inancı üzerindeki olumsuz etkileri ortadan kaldırmak açısından önemlidir. 


\section{Öğretme/Öğretmen Yeterliliği}

Öğretme/öğretmen öz-yeterliği, öz-yeterlik çalışmalarının eğitimle ilişkili bir alanıdır (Henson, 2001, s. 4). Öğretme/öğretmen yeterliği ile ilgili çalışmalar 1980'lerde başlamış ve biri Rotter'ın (1966) denetim odağı (locus of control) kuramı, diğeri Bandura'nın (1977) sosyal öğrenme kuramı olmak üzere iki kuramın etkisi altında kalmıştı. Araştırmacıların bu kuramları yorumlama farklılıkları öğretmen yeterliği ve öğretmen yeterliğinin ölçümü konularında bazı karışıklıklara neden olmakla birlikte öğretmen yeterliği eğitim araştırmalarında önemli bir alan olarak varlığını korumaktadır (Woolfolk ve Hoy, 1990, s. 81).

"Denetim odağı", Rotter'ın kuramının; "öz-yeterlik" de Bandura'nın kuramının temelini oluşturan kavramlardır. Denetim odağının öz-yeterliği etkileyebileceği görüşünü savunanlar olmakla beraber (Henson, Kogan, Vacha-Haase, 2001, s. 406; Gordon, Lim, McKinnon ve Nkala, 1998, s. 55), Bandura gibi aksi düşünce de olan araşıırmacılar da vardır (Tschannen-Moran, Woolfolk Hoy ve Hoy, 1998, s. 7). Sonuç olarak, her ikisinin de öğrenme sürecinde ve öğretme/öğretmen başarısında önemli rol oynadığı bilinmektedir (Stein ve Wang, 1988, s. 174). Yeterlilik belli bir alan, durum ve iş ile ilişkiliyken; denetim odağı, kişinin dünyaya/olaylara genel bakış açısıyla ilişkilidir (Gordon, Lim, McKinnon ve Nkala, 1998, s. 55).

Öğretme/öğretmen yeterliği, öğrencilerde öğrenme eylemini gerçekleştirme, öğrencilerden istenen sonucu alma kapasiteleri konusunda öğretmenlerin kişisel yargıları; diğer bir deyişle, öğretmenlerin, öğrencilerin performanslarını ve davranışlarını etkileme yeteneklerine olan inançları olarak tanımlanır (Gordon, Lim, McKinnon ve Nkala, 1998, s. 53). Bu inancın öğretme etkinliği üzerinde güçlü etkileri vardır. Güçlü yeterlik inancı taşıyan öğretmenler, öğrenci başarısını ve motivasyonunu kontrol edebileceklerine, en azından etkileyebileceklerine inanırlar (Tschannen-Moran, Woolfolk Hoy ve Hoy, 1998, s. 202). Ashton (1984, s. 28), başka hiç bir öğretmen özelliğinin öğrenci başarısı ile bu kadar tutarlı ilişki göstermediğini, Smylie (1990, s. 48), ise öğretme/öğretmen yeterliğinin, öğretmen performansını etkileyen sosyopsikolojik faktörlerin başında geldiğini belirtir.

Araştırmalar sonucunda, ögretmenlerin öğretme yeterliği ile öğrenci başarISI (Gibson ve Dembo, 1984; Ashton ve Webb, 1986; Ross, 1992), öğrenci 
motivasyonu (Midgley, Feldlaufer ve Eccles, 1989) ve öğrencilerin kişisel yeterlik inançları (Anderson, Greene ve Loewen, 1988; Tschannen-Morgan ve Woolfolk Hoy, 2001) arasında anlamlı ve güçlü ilişkiler olduğu kanıtlanmıştır.

Araştırmacılar, öğretme/öğretmen yeterliğini öğretme davranışları, öğretmen performansı ve öğretmenlerin sınıf yönetimi stratejileri ile de ilişkilendirmiştir. Yeterlik duygusu öğretmenlerin öğretmek için gösterdikleri gayreti etkilemektedir (Tschannen-Moran ve Woolfolk Hoy, 2001, s. 783). Öğretme yeterliği inancı güçlü olan öğretmenlerin, bu alanda inancı zayıf olanlara göre daha başarılı uygulamalar gerçekleştirdikleri; öğrencilerle daha olumlu ilişkiler geliştirdikleri; öğrenci hatalarına karşı daha hoşgörülü oldukları; öğrenci başarısı açısından daha yüksek beklentiler taşıdıkları; yeni fikirlere daha açık oldukları; sınıfta daha istekli davrandıkları; öğrenci başarısında sorumluluk kabul ettikleri; öğrencilerin gereksinimlerini daha iyi karşılamak için yeni yöntemler ve yeni öğretim materyalleri kullanmaya istekli ve yatkın oldukları; yeni öğretim planları ve stratejileri geliştirdikleri; yeni programlar uyguladıkları; öğrencilerin öğrenme güçlükleri karşısında ve herhangi bir sorunla karşılaştıklarında daha ısrarcı ve dayanıklı oldukları saptanmıştır (Henson, 2001, s. 2; Henson, Kogan, Vacha-Haase, 2001, s. 404; Lin ve Tsai, t.y.; Gordon, Lim, McKinnon ve Nkala, 1998, s. 54).

Öğretme/öğretmen yeterlik duygusunu etkileyen faktörler hakkında bilgi sahibi olmak, öğretmenlerin yeterlik algısını güçlendirmek açısından önemlidir. Öz-yeterlik algısını etkileyen dört temel faktör burada da etkilidir. Bunların dışındaki bazı faktörlerden de söz etmek olasıdır. Kısaca özetlemek gerekirse; bilgi birikimi gibi öğretmen ile ilgili değişkenler; sınıf mevcudu gibi sınıf değişkenleri; okul müdürünün yaklaşımı ve desteği gibi yönetimle ilgili değişkenler; öğretmenlerin sosyal statüleri gibi sosyo-ekonomik değişkenler; öğretim materyalleri/kaynakları, toplumdan ve meslektaşlardan gelen destek/onay gibi çevresel faktörlerden söz edilebilir (Tschannen-Moran ve Woolfolk Hoy, 2002, s. 2; Lin ve Tsai, t.y.). Nitekim, deneyimli öğretmenlerle mesleğe yeni başlayanlar üzerinde yapılan karşılaştırmalı çalışmalar öğretmenlerin bilgi birikimi ve deneyimlerinin öğretmen yeterliği üzerinde etkili olduğunu ortaya çıkarmıştır (Lin ve Tsai, t.y.). 
Öğretme/öğretmen yeterliğinin iki boyutu vardır: Birincisi, "kişisel öğretme yeterliği" (personal teaching efficacy), ikincisi "genel öğretme yeterliği” (general teaching efficacy - GTE) olarak adlandırılmaktadır. Kişisel öğretme yeterliği, kişinin kendi öğretme yeteneğinin öğrenci gelişimine katkısı konusundaki inancıdır. Genel öğretme yeterliği ise, kişinin diğer öğretmenlerin ve eğitim sisteminin bir bütün olarak öğrenciye yardımcı olma kapasitesi hakkındaki inancıdır (Lin ve Tsai, t.y.; Henson, Kogan, Vacha-Haase, 2001, s. 405; Gordon, Lim, McKinnon ve Nkala, 1998, s. 54).

Öğretme/öğretmen yeterliği iki alandaki yeterlik inancıyla ilişkilidir: Biri öğretmenin öğrettiği konudaki/alandaki yeterliği, diğeri öğretmenin öğretmek konusundaki, pedagoji alanındaki yeterliğidir (Koul ve Rubba, 1999; Lin ve Tsai, t.y.). Alan bilgisi tek başına mükemmel öğretmenler yaratmaz, başarılı bir öğretmen olabilmek aynı zamanda kişinin sağlam bir pedagoji bilgisi/ temeli olmasını, nasıl öğreteceğini bilmesini ve bu konuda kendine güvenmesini gerektirir (Lin ve Tsai, t.y.). Yeterlilik inancı alana/konuya bağlıdır ve bir öğretmenin ilgili alanda/bilim dalında güçlü yeterlik duygusuna sahipken, pedagoji alanında kendisini yetersiz hissetmesi olasıdır (Koul ve Rubba, 1999). Sonuç olarak, söz konusu iki alandan birinde yetersizlik duygusu öğretme yeterliğine yansımaktadır.

\section{Öz-Yeterlik ve Öğretme Yeterliğinin Bilgi Profesyonelleri İçin Önemi}

"Öz-yeterlik" ve "öğretme yeterliği” kavramlarının ne oldukları ve niçin önemli oldukları tartışıldıktan sonra, bilgi profesyonelleri için öneminin açıklanmasının da yararlı olacağı düşünülmektedir. Bilgi profesyonellerinin her şeyden önce başarılı bir iş performansı gösterebilmeleri için çalıştıkları alanda güçlü öz-yeterlik inancına gereksinimleri vardır. Bu sayede güçlüklerle karşılaştıklarında mücadele etme, sonuca ulaşana, bir çözüm üretene kadar sorunun üzerine gitme eğilimleri artar.

Öz-yeterlik inancının önemli olduğu alanlardan biri de yaşam boyu öğrenmedir. Yaşam boyu öğrenme, bireylerin kendi kendilerini yönlendirmelerini ve bilgi problemi çözme eylemlerini kendi istekleriyle gerçekleştirmelerini gerektirir. Bu durum, yaşam boyu öğrenme için temel beceriler olarak kabul edilen bilgi ve bilgisayar okuryazarlığı becerilerine sahip olmak kadar bu becerileri etkin şekilde kullanabilmek için öz-yeterlik inancı geliştirmeyi zorunlu kılar. 
Günümüzde değişmeden varlığını koruyabilen herhangi bir meslek kalmamıştır. Hangi meslek grubundan olursa olsun herkesin bilgisini sürekli olarak yenilemesi gereği vardır. Bilgi çevresinde gerçekleşen değişiklikler (bilgi artışı, bilginin öneminin artması, katma değerli bilgi hizmetlerine duyulan gereksinimin hızla artması, bilginin depolandığı ortamların değişmesi, teknolojik gelişmeler) göz önüne alındığında yaşam boyu öğrenme gereksiniminin bilgi profesyonelleri için vazgeçilmez önemi ortaya çıkmaktadır. Bugün bir bilgi profesyonelinin üniversiteden mezun olduğu bilgilerle mesleğinde başarılı bir performans gösterebileceği süre giderek kısalmaktadır. Sonuç olarak, yaşam boyu öğrenme bilgi profesyonelleri için kaçınılmazdır ve yaşam boyu öğrenme faaliyetine girişmesi için kişinin öncelikle bilgi ve bilgisayar okuryazarlığı alanlarında sağlam bir bilgi temeli ve güçlü öz-yeterlik algısına gereksinimi vardır (Kurbanoğlu, 2003, ss. 635-636). Bilgi profesyonellerinin bilgi ve bilgisayar okuryazarlığı becerileriyle donanmaları aldıkları eğitimin kaçınılmaz sonucudur. Ancak, öz-yeterlik eksikliği söz konusu becerilere sahip olmalarına rağmen bu becerileri kullanmamaları ve yaşam boyu öğrenme alanında gayret göstermemeleri ile sonuçlanabilir. Kendi kendisini yönlendiren, yaşam boyu öğrenebilen bireyler haline gelebilmeleri için herkes gibi bilgi profesyonellerinin de bilgi becerileri konusunda güçlü öz-yeterlik algısı geliştirmeleri gerekmektedir.

Bilgi profesyonelleri meslekleriyle ilgili hemen her türlü etkinlikte teknolojiden yararlanmaktadır. Bilgiye, hızlı ve nitelikli bilgi hizmetlerine duyulan gereksinimin sürekli olarak artması hemen her yeni teknolojinin bilgi hizmetleri alanında kullanılması olanağının araştırılması ile sonuçlanmaktadır. Bu durum, bilgi profesyonellerinin teknoloji alanında bilgi sahibi olmalarını gerektirdiği kadar güçlü bilgisayar öz-yeterlik inancına sahip olmalarını da gerektirmektedir.

Bilgisayar okuryazarlığı, bilgisayarlarla neler yapılabileceğini anlama ve onları etkin şekilde kullanmak için gerekli becerilere sahip olma şeklinde tanımlanmaktadır (Bawden, 2001). Bilgisayar okuryazarlığı yanı sıra bilgisayar öz-yeterlik algısı üzerinde de çok sayıda çalışma yapılmıştır (Bkz: Karsten ve Roth, 1998; Compeau ve Higgins, 1995; Hill, Smith ve Mann 1987; Akkoyunlu ve Kurbanoğlu, 2003). Yapılan çalışmalar genellikle öz-yeterlik algısı ile başarı arasındaki ilişkiye yönelik çalışmalardır. Bilgi problemi çözme becerile- 
ri, diğer bir deyişle, bilgi gereksiniminin tanımlanması, bilginin aranması, bulunması, değerlendirilmesi, kullanılması ve iletimiyle ilgili beceriler şeklinde tanımlanan (American Library Association, 2000; Association of College and Research Libraries, 2001) bilgi okuryazarlığı da özellikle son yıllarda üzerinde çok durulan araştırma konularından biridir. Literatürde bilgi okuryazarlığı üzerine çok sayıda çalışma olmasına rağmen Neely'nin de (2002) belirttiği gibi bilgi okuryazarlığını etkileyen sosyal ve psikolojik faktörler üzerinde fazla durulmamıştır. Dolayısıyla bilgi okuryazarlığı alanında öz-yeterlik algısını ele alan çalışmaların sayısı son derece sınırlıdır (Bkz: Grassian ve Kaplowitz, 2001; Carson, 1993; Akkoyunlu ve Kurbanoğlu, 2003; Kurbanoğlu, 2003). Söz konusu çalışmalarda bilgisayar ve bilgi okuryazarlığı becerilerinin öneminin yanı sıra bu alanlarda öz-yeterlik inancı geliştirmenin bu becerilerin etkin şekilde kullanılması açısından önemi de ortaya konmaktadır.

Tüm bunların yanı sıra bilgi profesyonellerinin kullanıcı eğitimi/bilgi okuryazarlığı eğitimi alanında yüklendikleri sorumluluklar olaya yeni bir boyut daha getirmekte, bilgi okuryazarlığı programları çerçevesinde öğretecekleri konular, bilgi okuryazarlığı alanında öz-yeterlik algısı geliştirmelerini, işin eğitim-öğretim boyutu, öğretme/öğretmen yeterliği geliştirmelerini gerektirmektedir. Öz-yeterlik inancı geliştirebilmeleri için söz konusu alanlarda önce bilgi sonra deneyim sahibi olmaları zorunludur.

Sonuç olarak, bilgi okuryazarlığı eğitimi verecek bilgi profesyonellerinin hem bilgi ve bilgisayar okuryazarlığı, hem de öğretim yöntem ve teknikleri, öğrenme kuramları, ölçme ve değerlendirme, sınıf yönetimi gibi pedagoji alanlarında bilgi sahibi olmaları gerekmektedir (Carson, 1993, s. 166; Grassian ve Kaplowitz, 2001, s. 34; Oberman, 2002, ss. 1-5; Markless, 2002, ss. 1-4; American Association of School Librarians ve Association for Educational Communications and Technology, 1988, ss. 38-39). Öğretme/ öğretmen yeterliği başlığı altında açıklandığı gibi bu alanlarda bilgi sahibi olmak da yeterli değildir, öğreten pozisyonundaki kişinin öğrenci başarısını etkileme konusundaki yeteneğine inanması, diğer bir deyişle, güçlü bir öğretme yeterliği inancına sahip olması gerekmektedir. Bu sayede yeni öğretim yöntem ve tekniklerini uygulamaya açık, öğrencilere karşı sabırlı, öğrenci başarısındaki sorumluluğunu kabul eden bir öğretici olarak öğrenci başarısını etkilemesi olasılığı daha yüksektir. 


\section{Sonuç ve Öneriler}

Bilgi profesyonellerinin gerek çalıştıkları alan, gerekse bilgisayar ve bilgi okuryazarlığı alanlarında öz-yeterlik inançlarını geliştirmiş olmalarının yanı sıra kullanıcı eğitimi verenlerin pedagoji alanında da yeterlilik inancı geliştirmelerinin performanslarını olumlu yönde etkileyeceği anlaşılmaktadır.

Bilgi merkezlerinde çalışmakta olan bilgi profesyonellerinin bilgisayar ve bilgi okuryazarlığı alanlarındaki eksiklerinin tamamlanması için önlemler alınması faydalı olacaktır. Bu amaçla sürekli eğitim ve/veya hizmet içi eğitim kapsamında programlar düzenlenmesi düşünülebilir. Bunun dışında bilgi profesyonellerinin mesleki toplantılara, bilgi ve belge yönetimi bölümleri veya dernekler tarafından düzenlenen semirlere katılımları teşvik edilmelidir. Öncelikle her bilgi merkezinin kendi elemanlarının bilgi eksikliklerini saptaması, sonra, bu eksikliklerin giderilmesi için çözümler üretmesi önerilebilir. Elemanlarının bilgi eksikliklerinin giderilmesi konusunda bilgi merkezlerinin kendi içlerinde veya bağlı bulundukları kurumlar bünyesinde çözümler üretmesi de olasıdır. Bilgi merkezlerinin kendi içlerinde çözüm üretemedikleri durumlarda diğer bilgi merkezleriyle, derneklerle, üniversitelerimizdeki bilgi ve belge yönetimi bölümleriyle işbirliği olanakları araştırılabilir.

Kullanıcı eğitimi/bilgi okuryazarlığı eğitimi veren bilgi profesyonelleri için ayrıca pedagoji alanındaki bilgi ve becerilerini artırmaya yönelik çözümler düşünülmelidir. Üniversite ve okul kütüphaneleri için bu alanda kurum içinde destek bulmak diğer bilgi merkezlerine göre daha kolay olacaktır. Eğitimciler tarafından verilecek seminerlerin bu alandaki bilgi açığının kapatılmasına katkısı olacaktır. Ayrıca kullanıcı eğitimi veren kütüphanecilerin, eğitim fakültelerinin düzenledikleri tezsiz yüksek lisans programlarına devam etmesi teşvik edilebilir.

Gerek bilgisayar ve bilgi okuryazarlığı, gerekse pedagoji alanlarında bilgi ve beceri eksiklerinin tamamlanmasının yanı sıra bilgi profesyonellerinin bu alanlardaki öz-yeterlik inançlarının güçlendirilmesi için pozitif deneyimlerini artırıcı uygulamalar planlanmalıdır. Daha önce de belirtildiği gibi, öz-yeterlik inancını artıran en önemli faktörlerden biri deneyimlerdir.

Sadece çalışmakta olan bilgi profesyonelleri için değil yetişmekte olan bilgi profesyonelleri için de önlemler düşünülmeli, Bilgi ve belge yönetimi 
bölümlerinin programları söz konusu bilgi ve becerileri kazandırma ve öğrencilere üniversite yıllarında bu alanlarda öz-yeterlik inancı geliştirmeleri konusundaki katkıları açısından gözden geçirilmeli, varsa eksikliklerin giderilmesi yoluna gidilmelidir. Bilgi ve belge yönetimi bölümlerinde özellikle stajlar ve uygulama dersleri öğrencilere pozitif deneyimler kazandırma kapasiteleri açısından değerlendirilmeli gerekiyorsa yeniden ele alınarak düzenlenmelidir.

Her türlü eğitim programı için değerlendirmede öğrencilerin/katılımcıların bilgi düzeylerinin yanı sıra öz-yeterlik düzeylerinin ölçümü önerilebilir. Böylece eğitim programlarının sadece bilgi değil aynı zamanda deneyim kazandırma kapasitelerinin değerlendirilmesi olanağı doğar. Nitekim, Hacettepe Üniversitesi Bilgi ve Belge Yönetimi Bölümü öğrencilerinin bilgisayar ve bilgi okuryazarlığı öz-yeterlik düzeyleri üzerine yürütülen bir çalışmadan elde edilen sonuçlar öğrencilerin özellikle bilgisayar öz-yeterlik inançlarının çok gelişmediğini ortaya koymuştur. Öğrencilerin bilgi okuryazarlığı öz-yeterlik düzeylerine gelince, birinci sınıfla son sınıf arasında bu alandaki bilgi ve deneyimlerinin arttığı düşünülerek öz-yeterlik algılarının da artması beklenen öğrencilerin öz-yeterlik düzeylerinde anlamlı bir değişiklik olmadığı ortaya çıkmıştır (Kurbanoğlu, 2003). Bu bulgular, eğitim programlarının, öğrencilere deneyim kazandırmaya yönelik uygulama dersleri açısından gözden geçirilmesi gerektiğini ortaya koymaktadır.

Öğretme yeterliğinin pedagoji bilgisi gerektirmesi bu alanda bilgi ve belge yönetimi bölümlerinin programlarına seçmeli dersler konulması ile çözümlenebilir. Söz konusu derslerle gereksinim duyacakları bilgi alt yapısını kazanacak öğrencilerin bilgi merkezlerinde kullanıcı eğitimi alanında çalıştıkları süreyle doğru orantılı olarak deneyimleri artacaktır. Bunun sonucunda öğretme yeterliği inançları gelişeceği için kullanıcı eğitimi/bilgi okuryazarlığı eğitimi alanında daha başarılı performans sergilemeleri beklenebilir. 


\section{Kaynakça}

Akkoyunlu, B. ve Kurbanoğlu, S. (2003). Öğretmen adaylarının bilgi okuryazarlığı ve bilgisayar öz-yeterlik algıları üzerine bir çalışma. Hacettepe Üniversitesi Eğitim Fakültesi Dergisi, 24, 1-10.

American Association of School Librarians ve Association for Educational Communications and Technology. (1988). Information power: Guidelines for school library media programs. Chicago: ALA.

American Library Association. (2000). Information literacy: A position paper on information problem solving. 21 Temmuz 2003 tarihinde http://www.ala.org/aasl/positions/PS_infolit.html adresinden erişildi.

Anderson, R., Greene, M. ve Loewen, P. (1988). Relationships among teachers' and students' thinking skills, sense of efficacy, and student achievement. Alberta Journal of Educational Research, 34 (2), 148-165.

Ashton, P. (1984). Teacher efficacy: A motivational paradigm for effective teacher education. Journal of Teacher Education, 35, 28-32.

Ashton, P. T. ve Webb, R. B. (1986). Making a difference: Teachers' sense of efficacy and student achievement. New York: Longman.

Association of College and Research Libraries (2001). Objectives for information literacy instruction: A model statement for academic librarians. 19 Şubat 2004 tarihinde ACRL web sitesinden erişildi: http://www.ala.org/acrl/acrlstandards/objectivesinformation.htm

Bandura, A. (1977). Self-efficacy: Toward a unifying theory of behavioral change. Psychological Review, 84, 191-215.

Bandura, A. (1986). Social foundations of thought and action: A social cognitive theory. Englewood Cliffs, NJ: Prentice-Hall.

Bandura, A. (1994). Self efficacy. V. S. Ramachaudran (Ed.). Encylopedia of human behavior içinde (Cilt 4, ss. 71-81). New York: Academic Press.

Bandura, A. (1995). Exercise of personel and collective efficacy in changing socities. A. Bandura (Ed.) Self-efficacy in changing socities içinde (ss. 1-45). Cambridge: Cambridge University Press.

Bawden, D. (2001). Information literacy and digital literacies: A review of concepts. Journal of Documentation, 57, 192-217. 
Carson, C. H. (1993). The development of a scale to measure the selfefficacy of school media specialists. School Library Media Quarterly, $21,165-170$.

Cassidy, S. ve Eachus, P. (2002). Developing the computer self-efficacy (CSE) scale: Investigating the relationship between CSE, gender and experience with computers. Journal of Educational Computing Research, 26, 133-153.

Compeau, D. R. ve Higgins, C. A. (1995). Computer self-efficacy: Development of a measure and initial test. MIS Quarterly, June, 189-211.

Delcourt, M. ve Kinzie, M. (1993). Computer technologies in teacher education: The measurement of attitudes and self-efficacy. Journal of Research and Development in Education, 27, 31-37.

Gawith, G. (1995). A serious look at self-efficacy: Or waking beeping Slooty. 8 Nisan 2003 tarihinde http://www.theschoolquarterly.com/ info_lit_archive/learning_thinking/95_g_g_aslasewbs.htm adresinden erişildi.

Gibson, S. ve Dembo, M. (1984). Teacher efficacy: A construct validation. Journal of Educational Psychology, 76, 569-582.

Gordon, C., Lim, L., McKinnon, D. ve Nkala, F. (1998). Learning approach, control orientation and self-efficacy of beginning teacher education students. Asia-Pacific Journal of Teacher Education \& Development, 1 (1), 53-63.

Grassian, E. S. ve Kaplowitz, J. R. (2001). Information literacy instruction: Theory and practice. New York: Neal-Schuman.

Havard, B. C. ve Atkinson, F. D. (t. y.). Factors influencing computer selfefficacy in an introductory level computer course. 6 Kasım 2001 tarihinde http://itechl.coe.uga.edu/designconference/PDFs/20.pdf adresinden erişildi.

Henson, R. K. (2001). Teacher self-efficacy: Substantive implications and measurement dilemmas. Annual Meeting of the Educational Research Exchange, January 26, 2001, Texas A \& M University'de sunulan bildiri. 
Henson, R. K., Kogan, L. R. ve Vacha-Haase, T. (2001). A reliability generalization study of the teacher efficacy scale and related instruments. Educational and Psychological Measurement, 61 (3), 404-420.

Hill, T., Smith, N. D., ve Mann, M. F. (1987). Role of efficacy expectations in predicting the decision to use advanced technologies: The case of computers. Journal of Applied Psychology, 72, 307-313.

Karsten, R. ve Roth, M. R. (1998). The relationship of computer experience and computer self-efficacy to performance in introductory computer literacy courses. Journal of Research on Technology Education, 31(1), 14-24.

Koul, R. ve Rubba, P. (1999). An analysis of the reliability and validity of personal Internet teaching efficacy beliefs scale. Electronic Journal of Science Education. 27 Aralık 2002 tarihinde http://unr.edu/homepage/ crowther/ejse/koulrubba.html adresinden erişildi.

Kurbanoğlu, S. (2003). Self-efficacy: A concept closely linked to information literacy and lifelong learning. Journal of Documentation, 59, 635-646.

Lin, S. S. J. ve Tsai, C. (t.y.). Teaching efficacy along the development of teaching expertise among science and math teachers in Taiwan. 30 Temmuz 2003 tarihinde http://www.educ.sfu.ca/narstsite/ conference/lintsai/lintsai.htm adresinden erişildi.

Markless, S. (2002). Learning about learning rather than about teaching. $68^{\text {th }}$ IFLA Council and General Conference, August 18-24, 2002, Glasgow'da sunulan bildiri.

Midgley, C., Feldlaufer, H. ve Eccles, J. (1989). Change in teacher efficacy and student self and task-related beliefs in mathematics during the transition to junior high school. Journal of Educational Psychology, 81, 247-258.

Neely, T. Y. (2002). Sociological and psychological aspects of information literacy in higher education. Lanham, Maryland: The Scarecrow. 
Oberman, C. (2002). What he ACRL Institute for Information Literacy Best Practices Initiative tells us about the librarian as teacher. $68^{\text {th }}$ IFLA Council and General Conference, August 18-24, 2002, Glasgow'da sunulan bildiri.

Pajares, F. (2002). Overview of social cognitive theory and of self-efficacy. 26 Aralık 2002 tarihinde http://www.emory.edu/EDUCATION/MFP /eff.html adresinden erişildi.

Ross, J. A. (1992). Teacher efficacy an the effect of coaching on student achievement. Canadian Journal of Education, 17 (1), 51-65.

Rotter, J. B. (1966). Generalized expectancies for internal versus external control of reinforcement. Psychological Monographs, 80, 1-28.

Smylie, M. (1990). Teacher efficacy at work. P. Reyes (Ed.), Teachers and their workplace içinde (ss. 48-66). Newbury Park, Cal.: Sage Pub.

Stein, M. K. ve Wang, M. C. (1988). Teacher development and school improvement: The process of teacher change. Teaching and Teacher Education, 4, 171-187.

Tschannen-Moran, M. ve Woolfolk Hoy, A. (2001). Teacher efficacy: capturing an elusive construct. Teaching and Teacher Education, 17, 783-805.

Tschannen-Moran, M. ve Woolfolk Hoy, A. (2002). The influence of resources and support on teachers' efficacy beliefs. The Annual Meeting of the American Educational Research Association. April 2, 2002. New Orleans, LA'da sunulan bildiri.

Tschannen-Moran, M., Woolfolk Hoy, A. ve Hoy, W. K. (1998). Teacher efficacy: Its meaning and measure. Review of Educational Research, 68, 202-248.

Woolfolk, A. E. ve Hoy, W. K. (1990). Prospective teachers' sense of efficacy and beliefs about control. Journal of Educational Psychology, 82, 81-91. 